\title{
エンジン音の影響を抑制するタイヤ音パワースペクトルの車上計測
}

\author{
黒山 喬允 ${ }^{* 1}$
}

\section{On-board measurement of power spectra of tire sound suppressing disturbance of engine sound}

\author{
Takanobu KUROYAMA*1 \\ ${ }^{* 1}$ Department of Electronic Control Engineering, National Institute of Technology, Gifu College \\ 2236-2 Kamimakuwa, Motosu-shi, Gifu 501-0495, Japan
}

Received: 15 May 2017; Revised: 6 August 2017; Accepted: 7 November 2017

\begin{abstract}
A reduction method of engine sound disturbance for on-board power spectral measurement of tire sound is proposed and its validity is evaluated. The proposed method employs two microphones; one is mounted in the engine compartment, and the other in the wheel well of the vehicle. At first, the sound propagation characteristics between the two microphones are discussed. It is shown that the complex coherence between the engine sounds obtained with two microphones are very low. On the other hand, the power coherence takes about 0.4 within the frequency range from 0 to $15 \mathrm{kHz}$. These imply that the sound does not propagate linearly between the two microphones, but the power spectra of microphones correlate each other. Next, the power spectra of the sound measured with each microphone are calculated and the power spectrum of the tire sound is extracted by the calculation with the two spectra based on a pre-identified transfer function between the two microphones. The calculated power spectrum of the tire sound depends on the driving conditions of the engine and its large variance is not acceptable. This may be caused by the error of the pre-identified transfer function. Then, the modified transfer function is determined and the power spectra are calculated again. As a result, the variance of the power spectra becames lower than previous results and thus, the validity of the proposed method is confirmed.
\end{abstract}

Keywords : Tire sound, Engine sound, Automobile, Power spectrum, System identification

\section{1. 緒言}

自動車交通は社会経済とともに大きく発展し，現在では社会にとって重要なシステムの一つとなっている。一 方で，その発達は多数の交通事故を引き起こし，加えて老朽化した道路の保守管理に要する費用の増大が問題と なっている。 また，道路交通音は沿道地域において主要な騒音源となっており，この騒音に対して適切な対策を 施すためにはエンジン音やタイヤ音などからなる自動車騒音（吉田, 平野, 2014）の特性を正確に把握し騒音予測 を行う必要がある。こうした問題の解決策として，情報技術の発展に根ざした Intelligent transport system (ITS) が 注目を集めている（国土交通省，2015）。ITS では各種のセンサを道路上や車上に設置し得た情報を活用すること で，円滑な自動車交通の実現を目指す。また，自動車の安全性を向上させる手段として衝突被害軽減ブレーキや自 動操舵など各種の運転支援技術が実用化されてきている．高度な運転支援を行うためには自動車のブレーキや旋 回性能に影響を与える路面状況を把握する必要があり，カメラ（山田他，2004）や夕イヤに内蔵した加速度セン サ（花塚他，2010），マイクロホン（鎌倉他，2015）を用いる計測法が提案されている.これらの手法の中でも著

\footnotetext{
No.17-00222 [DOI:10.1299/transjsme.17-00222], J-STAGE Advance Publication date : 16 November, 2017

*1 正員, 岐阜工業高等専門学校 電子制御工学科（干501-0495 岐阜県本巣市上真桑 2236-2)

E-mail of corresponding author: kuroyama@gifu-nct.ac.jp
} 
者はマイクロホンを用い測定したタイヤ音に基づき路面状況を検出する手法に着目してきた。車両と路面の唯一 の接触点である夕イヤから生じる夕イヤ音は, 路面の接触によってタイヤが振動し生じる路面加振音や夕イヤと 路面の摩擦によって生じる接地摩擦振動音等からなる（ブリジストン，2010）。これらの音は路面の凹凸や亀裂, 摩擦状態によって恋化するため, 夕イヤ音から夕イヤと路面の接触状態を知ることができる可能性がある.また, 路面亀裂に起因する音を取得でき, 衛星測位システムなどの情報をもとに取得場所を特定できれば道路の保守管 理を効率化できる（Chugh et al., 2014）。加えて，エンジン音に並んで自動車騒音の主な源である夕イヤ音を走行 中に取得できれば，沿道地域の騒音環境評価を行うことができると考える.

鎌倉らは路上に設置したマイクロホンを用いて取得したタイヤ音のパワースペクトルに基づき，冬タイヤにお いて特定周波数成分が卓越することから冬夕イヤと夏夕イヤを判別する手法や，湿潤状態では高い周波数成分が 広い帯域にわたつて生じることから路面の乾燥湿潤を判別する手法を実現した (鎌倉他, 2015)。また，マイクロ ホンを車上に設置することで車両走行経路上の広い地域における路面状況把握に向けた試みもなされている（上 田他，2009）。しかしながら, これらの先行研究ではエンジン音の影響は考慮されていない. 電気自動車が市販さ れる近年でも，多くの自動車は内燃機関を主たる動力源としており，夕イヤ音に基づいて路面状況を運転者にリ アルタイム提示するためにはエンジン音の影響を考慮する必要がある。特にマイクロホンを車上の夕イヤ近傍に 設置する場合，タイヤ付近には一般にエンジンや排気マフラーが存在していることから，エンジン音の影響は無 視できないものと考えられる。著者らは，これまでにエンジン音が夕イヤ音の計測に影響することを確認してお り，その影響を低減するための手法を提案してきた。提案手法では 2 個のマイクロホンをそれぞれタイヤハウス 内とエンジンルーム内に設置して, 両マイクロホンで取得した信号から信号処理によってエンジン音の影響を低 減する. 両マイクホン間での音波の線形伝搬を仮定した処理方法では夕イヤハウス内マイクで計測されるエンジ ン音を最大で $6 \mathrm{~dB}$ 程度しか低減できなかった（黒山，2016a）。また，同定したマイクロホン間の伝達関数に基づ きパワースペクトルの減算を行う処理方法では，線形伝搬を仮定した方法に比べればエンジン音の影響を大きく 低減できたが，パワースペクトルの分散が著しく大きくなるという問題点があった（黒山，2016b）.

そこで，本論文ではまず提案する計測システムの特性をコヒーレンス関数に基づいて解析する．上述の二つの 処理手法の結果に差異が生じた原因を議論し，2 個のマイクロホンを用いパワースペクトルに関する信号処理を行 うことによって, 複数の音源から生じる騒音のうち目的外の騒音の影響を低減する手法の有効性について述べる. 次に, 2 個のマイク間の伝達関数の推定精度を向上する手法を提案する.この伝達関数を用いてタイヤ音のパワー スペクトルを求め, 提案手法の妥当性を検証する.

\section{2. 計 測 原 理}

\section{$2 \cdot 1$ エンジン音の影響を考慮するタイヤ音パワースペクトルの計測}

提案する計測システムでは，2 個のマイクロホンから得た信号よりエンジン音の影響を除去し，タイヤ音のパ ワースペクトルのみを求める. 図 1 に示寸計測システムのとおり, マイクロホン 1 はエンジンルーム内に, マイク ロホン 2 は左前夕イヤハウスに設置する。、イクロホン 1,2 からの信号をそれぞれ $f_{\mathrm{i}}(t), f_{\mathrm{o}}(t)$ とするとき, 両 マイクロホン間で音波が線形伝搬すると仮定すれば，次のようにシステムをモデル化できる.

$$
f_{\mathrm{i}}(t)=m(t)+h_{\mathrm{oi}} * r(t)
$$

$$
f_{\mathrm{o}}(t)=r(t)+h_{\mathrm{io}} * m(t)
$$

ここで, $m(t)$ はマイクロホン 1 で測定されるエンジンから生じた音, $r(t)$ はマイクロホン 2 で測定される夕イヤ から生じた音であり， * は畳み込み積分を表す， $h_{\mathrm{oi}}(t)$ は夕イヤハウス内マイクロホンからエンジンルーム内マイ クロホンへのインパルス応答であり,$h_{\mathrm{io}}(t)$ はその逆経路のインパルス応答である. したがって $, m(t), r(t)$ はそ れぞれ音源であるエンジン，タイヤからマイクロホンまでの伝搬経路の特性を含むが，これ以降は区別せずに工 ンジン音, タイヤ音と呼ぶ. 式（1），(2) の両辺をフーリエ変換すれば,

$$
F_{\mathrm{i}}(\omega)=M(\omega)+H_{\mathrm{oi}}(\omega) R(\omega)
$$


(a)

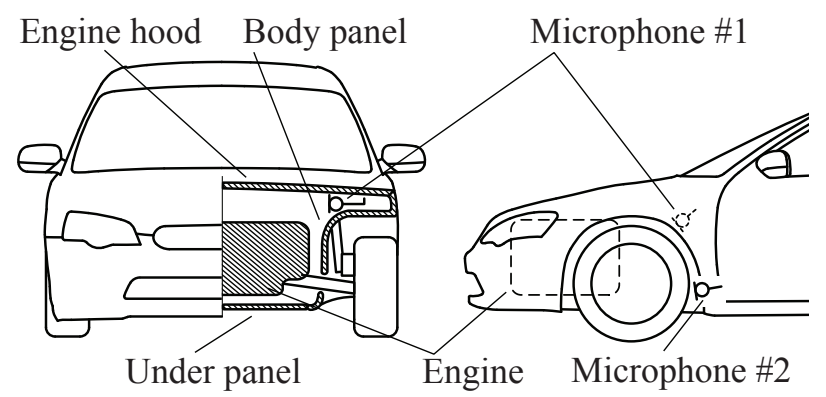

(b)

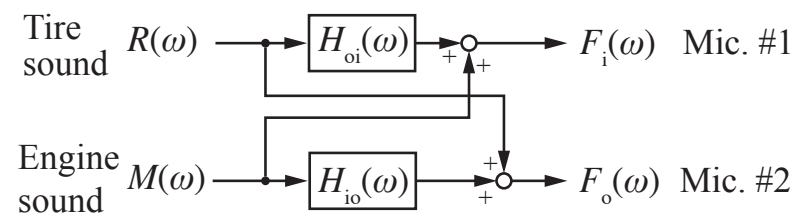

Fig. 1 Experimental system (a)alignment of microphones on testing vehicle (b)block diagram corresponding to experimental system.

$$
F_{\mathrm{o}}(\omega)=R(\omega)+H_{\mathrm{io}}(\omega) M(\omega)
$$

となる．ここで， $\omega$ は角周波数であり， $F_{\mathrm{i}}(\omega), F_{\mathrm{o}}(\omega), M(\omega), R(\omega), H_{\mathrm{oi}}(\omega), H_{\mathrm{io}}(\omega)$ はそれぞれ， $f_{\mathrm{i}}(t), f_{\mathrm{o}}(t)$, $m(t), r(t), h_{\mathrm{oi}}(t), h_{\mathrm{io}}(t)$ をフーリエ変換したものである. エンジン音，夕イヤ音に相関がないと仮定すればパワー スペクトルはそれぞれ

$$
\begin{aligned}
& \left|F_{\mathrm{i}}(\omega)\right|^{2}=|M(\omega)|^{2}+\left|H_{\mathrm{oi}}(\omega)\right|^{2}|R(\omega)|^{2} \\
& \left|F_{\mathrm{o}}(\omega)\right|^{2}=|R(\omega)|^{2}+\left|H_{\mathrm{io}}(\omega)\right|^{2}|M(\omega)|^{2}
\end{aligned}
$$

となる。式 (5)，(6) を連立して解けば，次式の通りタイヤ音のパワースペクトル $|R(\omega)|^{2}$ が得られる.

$$
|R(\omega)|^{2}=\frac{\left|F_{\mathrm{o}}(\omega)\right|^{2}-\left|H_{\mathrm{io}}(\omega)\right|^{2}\left|F_{\mathrm{i}}(\omega)\right|^{2}}{1-\left|H_{\mathrm{io}}(\omega)\right|^{2}\left|H_{\mathrm{oi}}(\omega)\right|^{2}}
$$

本論文では, 走行条件の違いによってタイヤ音パワースペクトルがどのように変化するかに着目する。このため, スペクトルの変化に影響を与えない分母の $\left|H_{\mathrm{io}}(\omega)\right|^{2}\left|H_{\mathrm{oi}}(\omega)\right|^{2}$ に関して, $\left|H_{\mathrm{io}}(\omega)\right|^{2}=\left|H_{\mathrm{oi}}(\omega)\right|^{2}$ と仮定し，

$$
|R(\omega)|^{2}=\frac{\left|F_{\mathrm{o}}(\omega)\right|^{2}-P(\omega)\left|F_{\mathrm{i}}(\omega)\right|^{2}}{1-P^{2}(\omega)}
$$

とする. ここで, $P(\omega)=\left|H_{\mathrm{io}}(\omega)\right|^{2}$ はパワースペクトルの伝達関数（これ以降パワースペクトル伝達関数と呼ぶ） を表す。エンジンルーム内マイクロホンからタイヤハウス内マイクロホンへの伝達関数 $H_{\mathrm{io}}(\omega)$ は, 車両停止時に $R(\omega)=0$ であることから式 (3)，(4)より，

$$
H_{\mathrm{io}}(\omega)=\frac{F_{\mathrm{o}}(\omega)}{F_{\mathrm{i}}(\omega)}
$$

と求めることができる. 同様に，パワースペクトル伝達関数 $P(\omega)$ も

$$
P(\omega)=\frac{\left|F_{\mathrm{o}}(\omega)\right|^{2}}{\left|F_{\mathrm{i}}(\omega)\right|^{2}}
$$

となる。

\section{2 標本信号からのパワースペクトルと伝達関数の推定}

同期したマイクロホン $1 ， 2$ からの信号をアナログ-ディジタル変換して得られた標本信号を, $N$ 点からなる $L$ 個 のフレームに分割しそれぞれ $f_{\mathrm{i}, l}(n), f_{\mathrm{o}, l}(n)$ とする. $n=(0,1, \cdots, N-1)$ は離散的時間を表し,$l=(0,1, \ldots, L-1)$ はフレーム番号である。 なお，各フレームは $N / 2$ ずつオーバーラップするものとし， $0 \leq k<N / 2$ に対して

$$
f_{\mathrm{i}, l}(k)=f_{\mathrm{i}, l-1}(k+N / 2)
$$


が成り立つようにフレームを定める，各フレームにおけるそれぞれの信号のスペクトル $F_{\mathrm{i}, l}(k), F_{\mathrm{o}, l}(k)$ は次式で与 えられる。

$$
\begin{aligned}
F_{\mathrm{i}, l}(k) & =\sum_{n=0}^{N-1} w(k) f_{\mathrm{i}, l}(n) \exp \left(-\mathrm{j} 2 \pi \frac{k n}{N}\right) \\
F_{\mathrm{o}, l}(k) & =\sum_{n=0}^{N-1} w(k) f_{\mathrm{o}, l}(n) \exp \left(-\mathrm{j} 2 \pi \frac{k n}{N}\right)
\end{aligned}
$$

ここで, $w(k)$ は空関数を表し, $k$ は離散周波数に対応する整数である. $k$ に対応する離散周波数 $f_{k}$ はサンプリン グ周波数 $f_{\mathrm{s}}$ を用いて次式で与えられる.

$$
f_{k}=\frac{k}{N} f_{\mathrm{s}}
$$

周波数分解能 $\Delta f$ は

$$
\Delta f=f_{k}-f_{k-1}=\frac{1}{N} f_{\mathrm{s}}
$$

である. パワースペクトルの推定值 $\left|\hat{F}_{\mathrm{i}}(k)\right|^{2},\left|\hat{F}_{\mathrm{o}}(k)\right|^{2}$ はそれぞれ,

$$
\begin{aligned}
& \left|\hat{F}_{\mathrm{i}}(k)\right|^{2}=E_{l}\left[\left|F_{\mathrm{i}, l}(k)\right|^{2}\right] \\
& \left|\hat{F}_{\mathrm{o}}(k)\right|^{2}=E_{l}\left[\left|F_{\mathrm{o}, l}(k)\right|^{2}\right]
\end{aligned}
$$

で求める。ここで, $E_{l}()$ は $l$ に関する平均操作を表す。この推定値の分散は概ね $L$ に反比例する（Welch, 1967）. したがって, 標本信号の信号長 $N L / 2$ を一定とすると, 周波数分解能と推定值の精度はトレードオフの関係にある. 伝達関数の推定值 $\hat{H}(\omega)$ はクロススペクトル法（日本音響学会, 1999）により次式で求める.

$$
\hat{H}(k)=\frac{E_{l}\left[F_{\mathrm{i}, l}^{*}(k) F_{\mathrm{o}, l}(k)\right]}{E_{l}\left[\left|F_{\mathrm{i}, l}(k)\right|^{2}\right]}
$$

またこのとき伝達関数の信頼性を表す複素コヒーレンス $\gamma_{\mathrm{c}}(k)$ は

$$
\gamma_{\mathrm{c}}(k)=\frac{E_{l}\left[F_{\mathrm{i}, l}^{*}(k) F_{\mathrm{o}, l}(k)\right]}{\sqrt{E_{l}\left[\left|F_{\mathrm{i}, l}(k)\right|^{2}\right] E_{l}\left[\left|F_{\mathrm{o}, l}(k)\right|^{2}\right]}}
$$

で与えられる。ここで, $F_{\mathrm{i}, l}^{*}(k)$ は $F_{\mathrm{i}, l}(k)$ の複素共役を表す. 複素コヒーレンスの位相は伝達関数の推定值の位相に 等しく, 二乗振幅は $0<\left|\gamma_{\mathrm{c}}(k)\right|^{2} \leq 1$ であり $f_{\mathrm{o}}(n)$ の中で $f_{\mathrm{i}}(n)$ と線形相関のある成分のパワー割合を表す.

同様に, パワースペクトル伝達関数の推定值 $\hat{P}(k)$ も次式で求める.

$$
\hat{P}(k)=\frac{E_{l}\left[\left|F_{\mathrm{i}, l}(k)\right|^{2}\left|F_{\mathrm{o}, l}(k)\right|^{2}\right]}{E_{l}\left[\left|F_{\mathrm{i}, l}(k)\right|^{4}\right]}
$$

パワーコヒーレンス $\gamma_{\mathrm{p}}(k)$ は次式で与えられる（坂田，2016）。

$$
\gamma_{\mathrm{p}}(k)=\frac{E_{l}\left\{\left[G\left[\left|F_{\mathrm{i}, l}(k)\right|^{2}\right] G\left[\left|F_{\mathrm{o}, l}(k)\right|^{2}\right]\right\}\right.}{\sqrt{E_{l}\left\{G\left[\left|F_{\mathrm{i}, l}(k)\right|^{2}\right]^{2}\right\} E_{l}\left\{G\left[\left|F_{\mathrm{i}, l}(k)\right|^{2}\right]^{2}\right\}}}
$$

ここで, $G()$ は $l$ に関して分散を保ったまま平均を 0 とする操作であり，次式で表される.

$$
G\left(\left|F_{\mathrm{i}, l}(k)\right|^{2}\right)=\left|F_{\mathrm{i}, l}(k)\right|^{2}-E_{l}\left[\left|F_{\mathrm{i}, l}(k)\right|^{2}\right]
$$

パワースペクトルは正の值のみをとるため, オフセットを除くためにこの操作が必要である。 パワーコヒーレン スは, $0<\gamma_{\mathrm{p}}(k) \leq 1$ であり, $f_{\mathrm{o}}(n)$ の中で $f_{\mathrm{i}}(n)$ とパワースペクトルに相関のある成分のパワー割合を表す. 以上 の定義から，マイクロホン間で音波が線形伝搬しない場合 $\left|\hat{H}_{\mathrm{io}}(k)\right|^{2} \neq \hat{P}(k)$ となる. 


\section{3. 実験結果と考察}

\section{$3 \cdot 1$ 計測システムの構成}

実験に用いた車両はセダン型の四輪駆動車であり，車両前部にエンジンルームを持つ．エンジンは 6 気筒，4 トロークサイクルであり，各気筒における燃燒は 2 回転のなかで等間隔に行われる。エンジンは傾面および上面 を鋼製のボディパネルとボンネットで，下面の一部を樹脂製のアンダーパネルで囲まれている. トランスミッショ ンは 6 段マニュアルであり，エンジン回転数と車速は比例する. $50 \mathrm{~km} / \mathrm{h}$ で走行した場合のエンジン回転数とトラ ンスミッションの減速比の関係を表 1 に示す。なお，タイヤ周長は $2,044 \mathrm{~mm}$ である.

図 1 の通り, エンジンルーム内マイクロホンは左前夕イヤハウスのフェンダー内側に, タイヤハウス内マイク ロホンは左前夕イヤハウス内の夕イヤ後方に埋め込むように取り付けた。なお，風雑音を抑制するため夕イヤハ ウス内マイクロホンはウィンドジャマーで覆った。両マイクロホンは $15 \mathrm{kHz}$ まで平坦な特性を持つマイクロホン カプセル (Panasonic WM-61A) と $10 \mathrm{~Hz}$ から $40 \mathrm{kHz}$ まで平坦な特性を持つ増幅器からなる。 マイクロホンから の信号はアナログ-ディジタル変換器を介して解析用計算機に取り込んだ。本計測ではマイクロホン間での音圧の 相対值の从が重要であるためマイクロホンの校正は行っていないが， $15 \mathrm{kHz}$ 程度まで音声を取得できることを確 認している．また，実験においては $30 \mathrm{kHz}$ まで暗騒音に比べて有意に大きなエンジン音のパワースペクトルが得 られることがわかっている。

\section{$3 \cdot 2$ エンジン音の周波数スペクトル}

図 2 に，停車時にエンジンを 3000 r.p.m.（50 Hz）で定常運転し，エンジンルーム内マイクロホンおよびタイヤ ハウス内マイクロホンで測定した音の時間波形とパワースペクトル密度を示す。時間波形は実験中に測定した音 圧の最大值で正規化している. パワースペクトル密度はフレーム長 $N=80,000$, フレーム数 $L=200$ とし, 八ミ ング空を用いて推定した。また，図 2 (c) にはエンジン停止時にタイヤハウス内マイクロホンで測定した暗騒音 のパワースペクトルも示した。 なお，本論文で示すパワースペクトルは全て聴感補正を行っていない.

エンジンルーム内，タイヤハウス内ともに $25 \mathrm{~Hz}$ とその高調波にあたる $50,75(\mathrm{~Hz})$ に鋭いピークが見られる. これは，4 ストロークサイクルの各気筒が 2 回転に 1 回燃焼を行うため, エンジン回転周波数が $50 \mathrm{~Hz}$ のとき各気 筒の燃焼周波数（単位時間当たりの燃燒回数）が $25 \mathrm{~Hz}$ となるためである.また $150 \mathrm{~Hz}$ にもピークが見られるが, これはエンジンが 6 気筒等間隔燃焼でありエンジン全体での燃焼周波数が $150 \mathrm{~Hz}$ となるためである。したがって, 両マイクで取得された信号はエンジンの燃焼に起因するものであると考えられ，両マイクロホンともにエンジン 音を取得できていることがわかる，また，暗騒音はマイクロホンが十分な感度を有する $15 \mathrm{kHz}$ 程度までの領域で, エンジン音よりも十分に小さい. タイヤハウス内マイクロホンからの信号のパワースペクトルはエンジンルーム 内よりも $3 \mathrm{kHz}$ 以上で $10 \mathrm{~dB}$ ほど小さい。これは，ボディパネル等によってエンジン音が減衰してタイヤハウス 内マイクロホンまで伝搬したためであると考吕れる.

エンジン音のスペクトルは上述の通りの鋭い近接したピークを持つが，測定対象である夕イヤ音はこのような ピークを持たない. このため以降は，フレーム長 $N=512$ として周波数分解能は $156 \mathrm{~Hz}$ とし，一方でフレーム数 $L$ を大きくしてパワースペクトルの推定精度を高め解析を行う。

Table 1 Final reduction ratio and rotational speed of engine with vehicle speed of $50 \mathrm{~km} / \mathrm{h}$.

\begin{tabular}{lcc}
\hline Gear & Reduction ratio & Rotational speed (r.p.m.) \\
\hline \hline First & 14.18 & 5,780 \\
Second & 8.716 & 3,553 \\
Third & 5.932 & 2,418 \\
Fourth & 4.434 & 1,808 \\
Fifth & 3.787 & 1,544 \\
Sixth & 2.948 & 1,202 \\
\hline
\end{tabular}



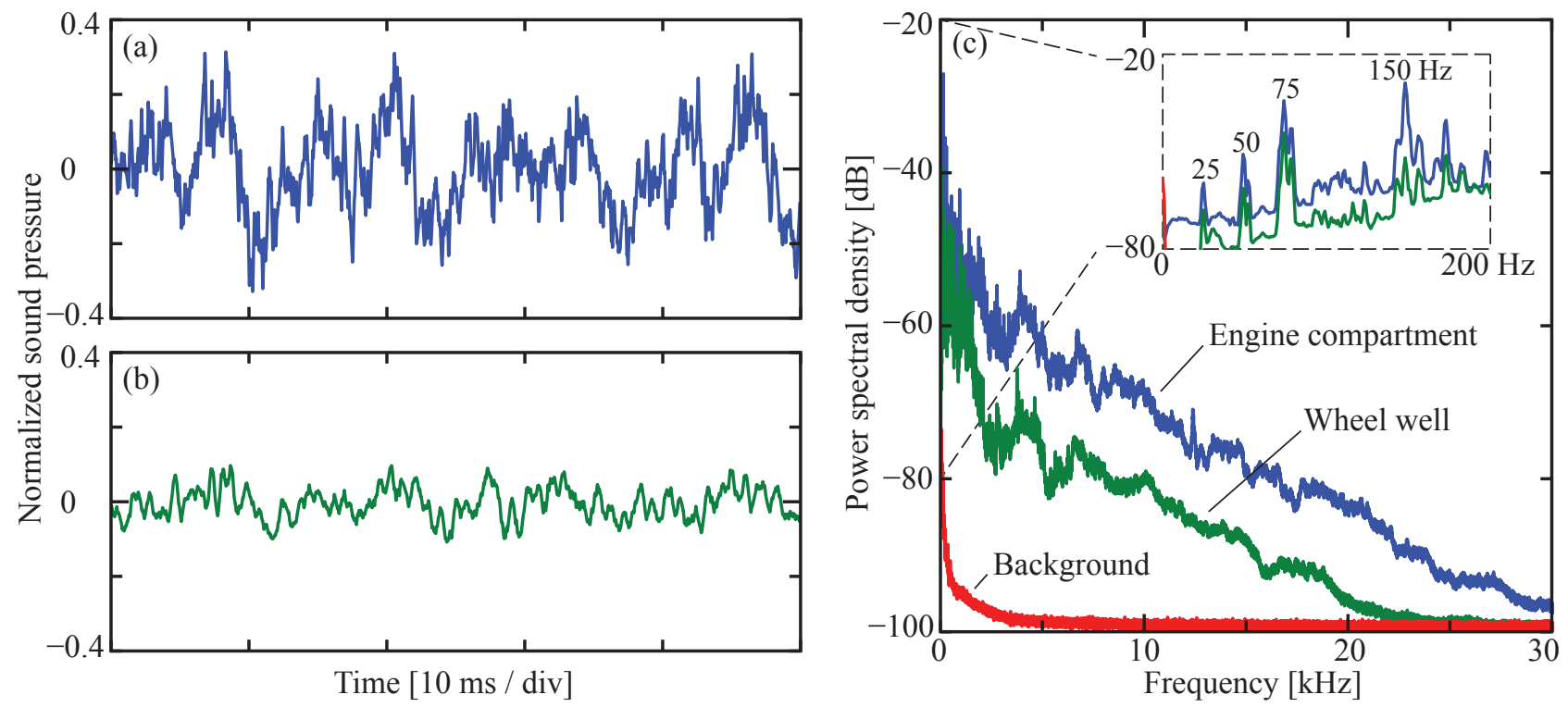

Fig. 2 Sounds measured during vehicle stop (a)temporal waveform in engine compartment and (b)in wheel well (c)power spectral density. Inset in (c): magnified view from $0 \mathrm{~Hz}$ to $200 \mathrm{~Hz}$.

\section{$3 \cdot 3$ マイクロホン間のコヒーレンス}

式（8）に基づくタイヤ音パワースペクトル計測の妥当性を検証するために，エンジンルーム内マイクロホンと タイヤハウス内マイクロホン間のコヒーレンスを計測した. 図 3 (a) , (b) に停車中にエンジン回転数を 1000 r.p.m. から 3000 r.p.m. の間で変動させながらエンジンルーム内マイクロホンとタイヤハウス内マイクロホンで計測した 音の時間波形をそれぞれ示す。エンジン回転数の増減とともにエンジン音が増減し，これに伴ってタイヤハウス 内マイクロホンで計測される音圧も増減している。図 $3(\mathrm{c})$ に複素コヒーレンスの二乗振幅 $\left|\gamma_{c}\right|^{2}(k)$ を，図 $3(\mathrm{~d})$ にパワーコヒーレンスを示す.

複素コヒーレンスの二乗振幅は $10^{-2}$ オーダと小さく，マイクロホン間に線形相関がほとんどないことを示して いる。これは，音源であるエンジンがボディパネルなどに囲まれており，これらによってエンジン音が反射され残 響が生じるためであると考えられる。残響音場におけるマイクロホン間の周波数伝達関数の位相は, 両マイクロホ ン間距離に比例する位相遅延と, 残響音によって不規則に変化する残響位相の両者からなる（高橋他，2006）。こ のため，本計測システムにおいては残響位相の影響によって周波数伝達関数の位相が不規則に変化するため，複 素コヒーレンスの二乗振幅が小さくなったと考えられる。したがって，式（1），(2）に基づく時間領域でのエン ジン音の影響抑制（黒山, 2016a）は実現が難しい.

一方で，パワーコヒーレンスは暗騒音に比べて十分に大きな音信号が得られる $15 \mathrm{kHz}$ までの領域において，0.4 程度となっており，両マイクロホンからの信号のパワースペクトルに相関があることを示している.このため，式 （8）に基づいて両マイクロホンで取得した音のパワースペクトルの線形結合からタイヤ音を求めることが可能で あると考えられる。

\section{4 パワースペクトル伝達関数}

図 4 に式（20）に基づいて推定したパワースペクトル伝達関数 $\hat{P}(k)$ を示す。推定には，(a）建物に囲まれた密 粒度アスファルト路面上，(b) 周囲に建物などがない砂利舗装された路面上に車両を停止させ，エンジンを 3000

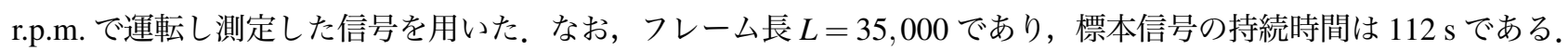
(a)，(b) のいずれの条件においても，パワースペクトル伝達関数は $0 \mathrm{~dB} よ り$ 小くなっておりエンジンから生じ た音は $-5 \mathrm{~dB}$ から $-20 \mathrm{~dB}$ の間で減衰してエンジンルーム内マイクロホンからタイヤハウス内マイクロホンに伝 搬することがわかる。 $2 \mathrm{kHz}$ までは， $2 \mathrm{kHz}$ から $20 \mathrm{kHz}$ までの周波数帯域に比べて減衰が小さくなっている。こ れは，エンジンで生じた振動がエンジンマウント等を介してボディパネルを振動させ，その振動や振動によって 生じた音波が夕イヤハウス内に伝わっているためであると考えられる。 $20 \mathrm{kHz}$ 以上においても再び減衰が小さく 

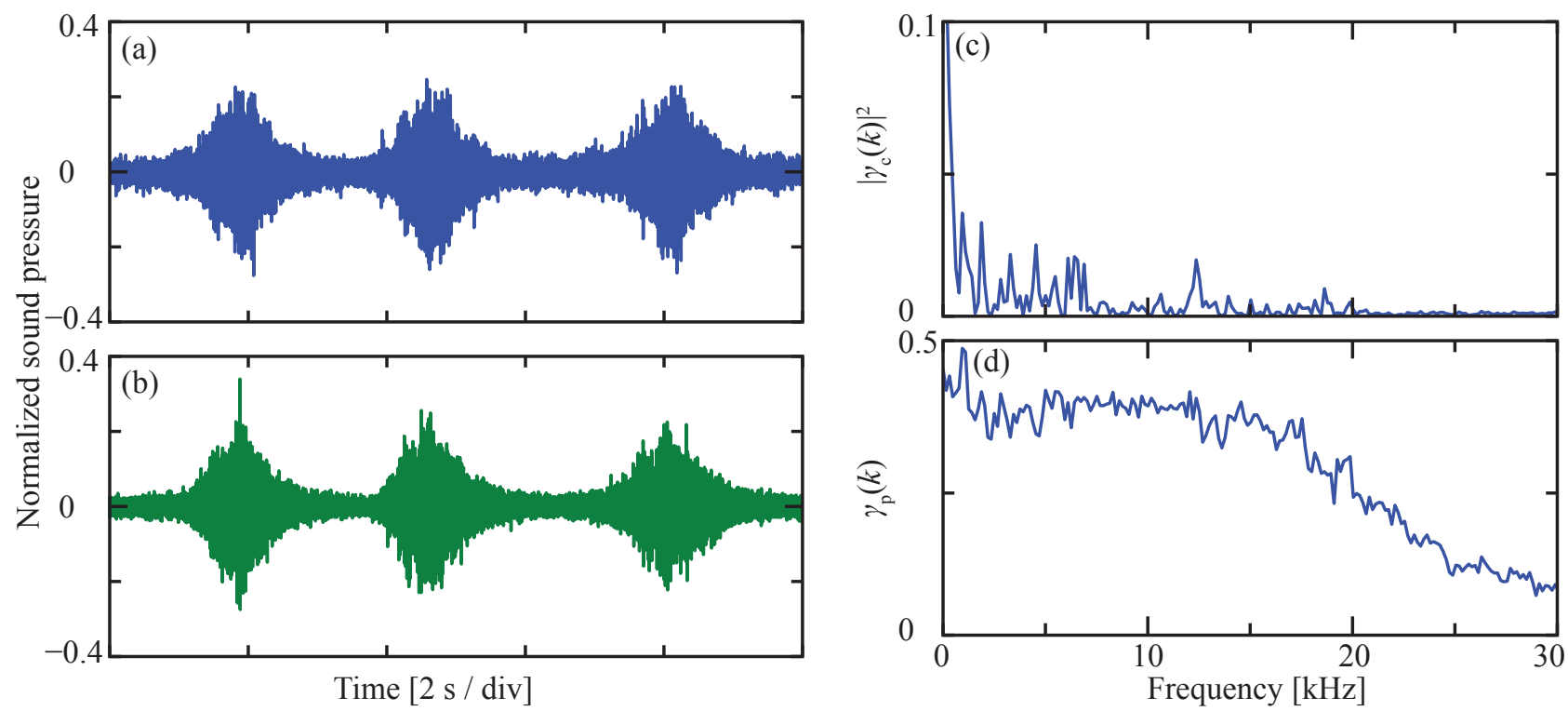

Fig. 3 Coherence between microphones in engine compartment and wheel well (a) fluctuating engine sound measured with microphone in engine compartment and (b)in wheel well, (c)squared amplitude of complex coherence (d)power coherence.

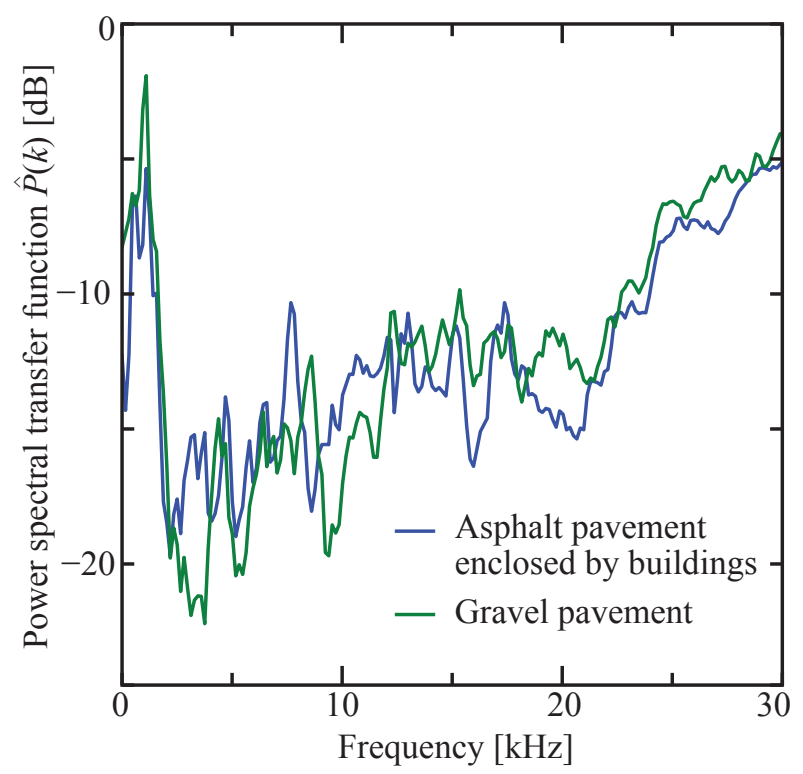

Fig. 4 Power spectral transfer function determined in two conditions.

なっているが，これはこの帯域のマイクロホンの感度が低く，両マイクロホンの出力より大きい定常的な電磁ノイ ズが信号に重畳したためであると考えられる。

舗装の条件によって，パワースペクトル伝達関数は最大 $5 \mathrm{~dB}$ ほど異なる。これは，舗装材によってエンジンルー ム下面から夕イヤハウス内に伝搬する音波の伝達特性が異なり, また車両周囲の建物によって反射された音波の 有無によって推定される伝達特性が変化するためであると考えられる. 加えて, 交通騒音などの環境音によって パワースペクトル伝達関数の推定精度が低下していることも考えられる。このため，事前に求めたパワースペク トル伝達関数の推定值を用いることでは, 道路上のように周囲に障害物が少なく舗装の異なる場所において十分 な精度で夕イヤ音パワースペクトルを求められない可能性がある. 

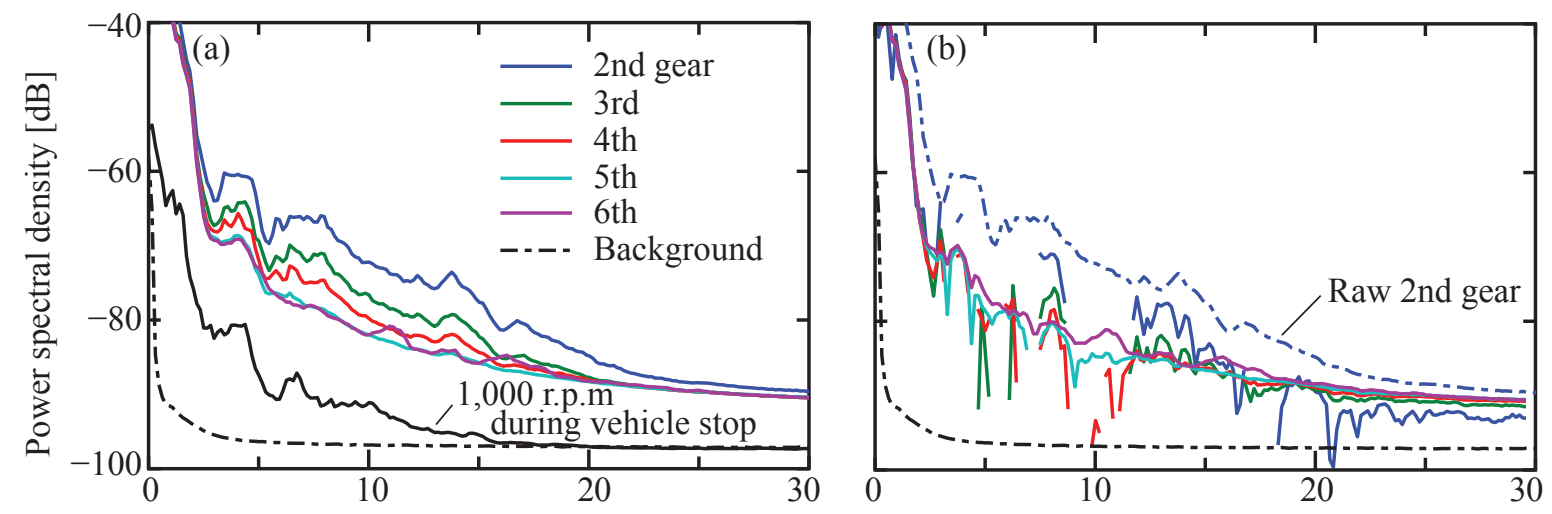

Frequency $[\mathrm{kHz}]$

Fig. 5 Power spectral estimation of tire sound with vehicle speed of $50 \mathrm{~km} / \mathrm{h}$ (a)raw power spectral density of sounds obtained by microphone in wheel well with several rotational speeds of engine (b)estimated power spectral density of tire sound.

\section{5 提案手法によって求めたタイヤ音のパワースペクトル}

図 5 （a）に密粒度アスファルト舗装の直線道路上を $50 \pm 3 \mathrm{~km} / \mathrm{h}$ の一定速度で走行し，タイヤハウス内マイクロ ホンで計測した信号のパワースペクトル密度を示す．図には停止時にエンジンを 1,000 r.p.m. で定常運転しタイヤ ハウス内マイクロホンで取得した信号と暗騒音のパワースペクトルも示す. フレーム長 $L=13,600$ であり, 標本 信号の持続時間は $43.5 \mathrm{~s}$ である。これは，約 $600 \mathrm{~m}$ の走行距離に相当する。車速を保ったまま変速段を 2 から 6 速まで変更しエンジン回転数を表 1 の通り変化させて, 道路の同一区間で計測を繰り返した。減速比を小さくし てエンジン回転数が小さくなるに従って，パワースペクトルも小さくなることがわかる．5 速と 6 速ではパワース ペクトルがほぼ等しくなっているが，これはエンジン回転数がそれぞれ 1,544 r.p.m. と 1,202 r.p.m. であり，停止 時 1,000 r.p.m. のパワースペクトルのようにタイヤハウス内マイクロホンで計測されるエンジン音がタイヤ音に比 べて無視できるほど小さい，すなわち $\left|F_{0}(\omega)\right|^{2} \approx|R(\omega)|^{2}$ となるためである。一方で， 2 速から 4 速では夕イヤ八 ウス内マイクロホンで取得されるタイヤ音には無視できないほどエンジンに起因する音が重畳する.

図 5 （b）に式（8）に基づいて求めた夕イヤ音のパワースペクトルを示す. 図には 2 速での走行時にタイヤハウ ス内マイクロホンで得た信号と暗騒音のパワースペクトルも示す。計算には図 4 に示したうち, パワースペクトル のばらつきをより小さくできた（b）のパワースペクトル伝達関数を用いた，タイヤ音のパワースペクトルは，精 度よく求められれば変速段によらず等しくなるはずであるがばらつきは大きい．また，パワースペクトルが負の 值をとつたために $\mathrm{dB}$ 表示のグラフで久落している部分が多く存在する。これは上述の通り，用いたパワースペク トル伝達関数が大きな誤差を持っていたためであると考えられる.

\section{6 伝達関数の補正}

上述のように, 事前に定めたパワースペクトル伝達関数は誤差が多く, 求めたタイヤ音パワースペクトルも誤 差が大きいものとなる。 そこで，走行中に得られたパワースペクトルからパワースペクトル伝達関数を推定する ことを考える．良好に推定ができれば，エンジン回転数によらず求めた夕イヤ音のパワースペクトルは一定とな り，その差は 0 となるはずである。したがって，タイヤ音パワースペクトル間の二乗誤差を最小とする $\tilde{P}(k) を ，$ $\tilde{P}(k)>0$ の制約のもとに求め孔ば良い. $i$ 速と $j$ 速に着目すると，式（8）ょり

$$
\begin{aligned}
\tilde{P}(k) & =\underset{P(k)>0}{\operatorname{argmin}}\left\{\left[\left|R^{[i]}(k)\right|^{2}-\left|R^{[j]}(k)\right|^{2}\right]^{2}\right\} \\
& =\underset{P(k)>0}{\operatorname{argmin}}\left\{\left[\frac{\left|F_{\mathrm{o}}^{[i]}(k)\right|^{2}-\left|F_{\mathrm{o}}^{[j]}(k)\right|^{2}-P(k)\left[\left|F_{\mathrm{i}}^{[i]}(k)\right|^{2}-\left|F_{\mathrm{i}}^{[j]}(k)\right|^{2}\right]}{1-P(k)^{2}}\right]^{2}\right\}
\end{aligned}
$$




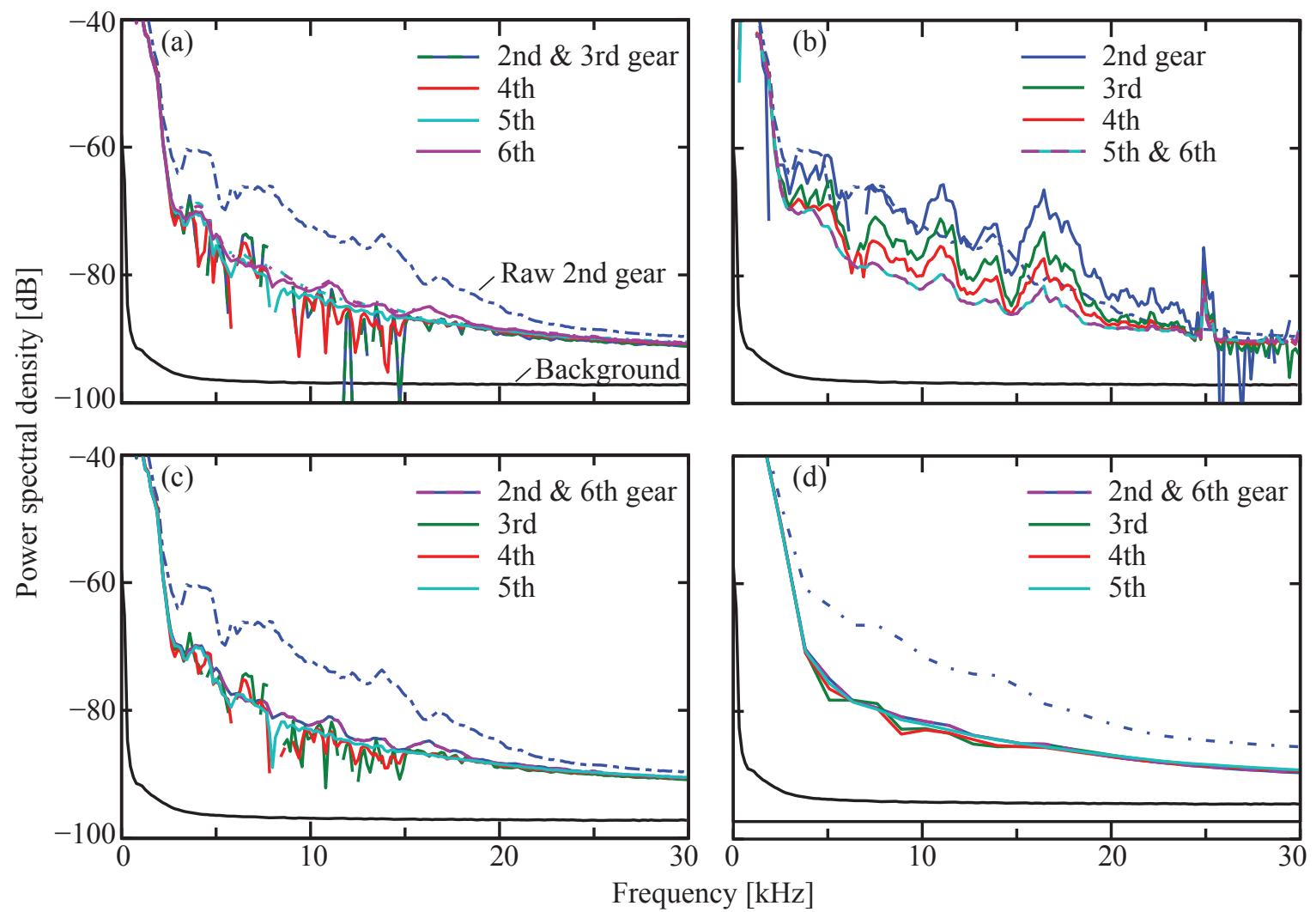

Fig. 6 Power spectral density of tire sound employing modified power spectral transfer function $\tilde{P}(k)$ estimated with (a)second gear and third gear (b) fifth gear and sixth gear (c), (d) second gear and sixth gear. $N=512$ and $L=13,600$ for (a)-(c). $N=64$ and $L=108,800$ for (d).

となる。ここで上付き添字 $[i]$ は $i$ 速を表す。特に， $\left[\left|F_{\mathrm{o}}^{[i]}(k)\right|^{2}-\left|F_{\mathrm{o}}^{[j]}(k)\right|^{2}\right] /\left[\left|F_{\mathrm{i}}^{[i]}(k)\right|^{2}-\left|F_{\mathrm{i}}^{[j]}(k)\right|^{2}\right]>0$ であれば，

$$
\tilde{P}(k)=\frac{\left|F_{\mathrm{o}}^{[i]}(k)\right|^{2}-\left|F_{\mathrm{o}}^{[j]}(k)\right|^{2}}{\left|F_{\mathrm{i}}^{[i]}(k)\right|^{2}-\left|F_{\mathrm{i}}^{[j]}(k)\right|^{2}}
$$

となる。

上式に基づき， 2 速と 3 速，5 速と 6 速，2 速と 6 速の結果から計算したパワースペクトル伝達関数を用いて求 めた夕イヤ音パワースペクトルを図 6 （a）－（c）に示す。それぞれ算出に用いた変速段同士の夕イヤ音パワース ペクトルは一致している. 2 速と 3 速，2 速と 6 速の結果を用いて求めた夕イヤ音パワースペクトルは図 5 （b）に 比べて変速段間のばらつきが小さくなっている一方で, 5 速と 6 速の結果を用いて求めた夕イヤ音パワースペクト ルはエンジン音の影響を除去できていない。これは，5 速と 6 速では共に夕イヤ音に比べてエンジン音が小さく， 式（25）の分子がほとんど 0 となりパワースペクトル伝達関数が過小評価されるためであると考えられる。最も 変速段間の夕イヤ音パワースペクトルのばらつきが小さい 2 速と 6 速を用いた結果においても， 3 速および 4 速に おける夕イヤ音パワースペクトルは 2 速および 6 速に対して最大で $8 \mathrm{~dB}$ ほど差が残っている。これは，夕イヤ音 パワースペクトルの推定に用いた $\left|\hat{F}_{\mathrm{i}}(k)\right|^{2}$ および $\left|\hat{F}_{\mathrm{o}}(k)\right|^{2}$ の推定誤差に起因するものであると考元れる.

タイヤ音パワースペクトルの推定値 $|\hat{R}(k)|^{2}$ とその分散 $V\left[|\hat{R}(k)|^{2}\right]$ は式（8）より

$$
\begin{aligned}
& \left|\hat{R}^{[i]}(k)\right|^{2}=\frac{\left|\hat{F}_{\mathrm{o}}^{[i]}(k)\right|^{2}-\tilde{P}(k)\left|\hat{F}_{\mathrm{i}}^{[i]}(k)\right|^{2}}{1-\tilde{P}^{2}(k)} \\
& V\left[\left|\hat{R}^{[i]}(k)\right|^{2}\right]=\left[\frac{1}{1-\tilde{P}(k)^{2}}\right]^{2}\left\{V\left[\left|\hat{F}_{\mathrm{o}}^{[i]}(k)\right|^{2}\right]+\left.\tilde{P}^{2}(k) V\left[\mid \hat{F}_{\mathrm{i}}^{[i]}(k)\right]\right|^{2}\right\}
\end{aligned}
$$

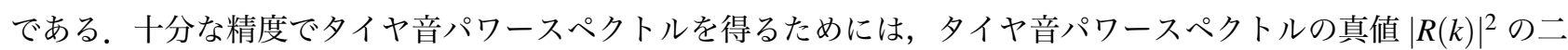


乗に対して十分小さな分散を持つ，すなわち変動係数 $c(k)$ の二乗值

$$
c^{2}(k) \equiv \frac{V\left[\left|\hat{R}^{[i]}(k)\right|^{2}\right]}{|R(k)|^{4}}
$$

が十分に小さい必要がある。ここで，パワースペクトル推定值の分散はそれぞれ $V\left[\left|\hat{F}_{\mathrm{i}}(k)\right|^{2}\right] \approx 1.2\left|\hat{F}_{\mathrm{i}}(k)\right|^{4} / L$, $V\left[\left|\hat{F}_{\mathrm{o}}(k)\right|^{2}\right] \approx 1.2\left|\hat{F}_{\mathrm{o}}(k)\right|^{4} / L$ であるため（Welch,1967），

$$
c^{2}(k)=\frac{1.2}{L} \frac{\left|\hat{F}_{\mathrm{o}}(k)\right|^{4}+\tilde{P}^{2}(k)\left|F_{\mathrm{i}}(k)\right|^{4}}{\left[1-\tilde{P}(k)^{2}\right]^{2}} \frac{1}{|R(k)|^{4}}
$$

となる. タイヤ音パワースペクトルの真值に代えて 6 速における推定值 $\left|\hat{R}^{[6]}(k)\right|^{2}$ を用いると，3 速の条件で変動 係数は最大 0.188 となった。これは測定值の $99.7 \%$ る. $L$ を 8 倍とすれば, 変動係数は $1 /(2 \sqrt{2})$ 倍となり, 誤差の範囲は $-1.93 \mathrm{~dB}$ から $1.58 \mathrm{~dB}$ となる. フレーム長 を $N=512 / 8=64$ に短縮し, フレーム数を $L=13,600 \times 8=108,800$ に増加させ推定したタイヤ音パワースペクトルを 図 6 （d）に示す．全ての変速段の結果が概ね一致していることがわかる．これは，両マイクで取得されるエンジ ンに起因する音のパワースペクトルに線形相関があることを示しており，また式（6）が成り立つことを表してい る. 以上から，パワースペクトル伝達関数の良好な推定值が得られ，スペクトル推定值の分散を十分に小さくで きるフレーム数 $L$ が達成されれば式（8）によってタイヤ音のパワースペクトルが求められることがわかる.

\section{4. 結言}

車上におけるタイヤ音のパワースペクトル計測において，エンジン音の影響をエンジンルームとタイヤハウス にそれぞれ設置した 2 個のマイクロホンからの信号に基づいて低減する手法を提案しその妥当性を検討した。停 車時にエンジンを運転しそれぞれのマイクロホンで音を計測した結果，両マイク間の信号の複素コヒーレンスの 2 乗振幅は $10^{-1}$ オーダと小さく，一方でパワーコヒーレンスは 0.4 程度であることがわかった。このことから，両 マイク間で音波は線形伝搬しないが，パワースペクトルには相関があることがわかった。計測システムのモデルと 予め同定したマイク間のパワースペクトル伝達関数に基づいて， $50 \mathrm{~km} / \mathrm{h}$ で走行時のタイヤ音のパワースペクト ルを求めた。しかしながら，求めたパワースペクトルの分散は無視できないほど大きなものなった。これは，パ ワースペクトル伝達関数の䛊差に起因することが考えられた。そこで, 新たに事前に走行して計測したパワース ペクトルからパワースペクトル伝達関数を求める手法を提案し, 本手法による結果をもとに夕イヤ音のパワース ペクトルを改めて求めた。 その結果, 先に求めたものよりも良好な結果が得られた。したがって, 現状では夕イ ヤ音を求めるために事前の走行による伝達関数推定が必要であるが，両マイクで取得した信号のパワースペクト ルの減算に基づいて対象とするタイヤ音のパワースペクトルを得る提案手法の妥当性が確認できた.

\section{文献}

ブリジストン，自動車用タイヤの基礎と実際 (2008)，第 4 章.

Chugh, G., Bansal, D. and Sofat, S., Road condition detection using smartphone sensors: A survey, International Journal of Electronic and Electrical Engineering, Vol. 7, No. 6 (2014), pp. 595 - 602.

花塚泰史, 森永啓詩, 若尾泰通, インテリジェントタイヤによる路面状況判別 -冬季道路管理への活用-, 日本雪工学 会 雪水研究大会 (2010).

鎌倉友男, 谷㟝徹也, 上田浩次, 冬タイヤ用音響同定システムの開発, IEICE Fundamentals Review, Vol. 9, No. 2 (2015), pp. $84-91$.

黒山喬允, 村上拓也, 森田栄吾, 車上タイヤ騒音計測のための線形系モデルに基づくエンジン騒音除去, 日本音響学 会 2016 年秋季研究発表会講演論文集 $(2016 a)$, pp. $773-774$.

黒山喬允, 村上拓也, 森田栄吾, 取得したエンジン騒音に基づきその影響を低減する車上タイヤ騒音計測, 日本音響 学会 騒音・振動研究会資料, N-2016-53 (2016b), 4 pages.

国土交通省, 国土交通白書 (2015), p. 308.

坂田直人, 村上哲郎, 中島弘史, 中臺一博, 2 チャンネル近接マイクロホンアレイによる風雑音の低減, 日本音響学会 誌, Vol. 72, No. 12 (2016), pp. 739 -748. 
日本音響学会編, 音・振動のスペクトル解析 (1999), 9 章.

高橋義典, 東山三樹男, 山崎芳男, 残響音場における位相周波数特性と直接音領域, 電子情報通信学会論文誌 A, Vol. J89-A, No. 4 (2006), pp. 291 - 297.

上田浩次, 谷嶲徹也, 中村香織, 小野寺浩, 鎌倉友男, 車の夕イヤ走行音に着目した路面状況検出, 平成 21 年電気学会 産業応用部門大会, No. 2-O5-3 (2010), pp. II-177 - II-182.

Welch, D. P., The use of fast fourier transform for the estimation of power spectra: A method based on time averaging over short, modified periodgrams, IEEE transactions on audio and electroacoustics, Vol. AU-15, No. 2 (1967), pp. 70-73.

山田宗男, 上田浩次, 堀場勇夫, 津川定之, 山本新, 画像処理による車載型路面状態検出センサの開発, 電気学会論文 誌 C, Vol. 124, No. 3 (2004), pp. 753 - 760.

吉田準史, 平野友寬, 独立成分分析を用いた自動車車内音の寄与分離に関する基礎検討 (応答信号のみを 用いたロードノイズとウィンドノイズの分離)，日本機械学会論文集，Vol. 80，No. 812 (2014)，DOI: 10.1299/transjsme.2014trans0063.

\section{References}

Bridgestone ed., Pneumatic tire technology (2008), Section 4 (in Japanese).

Chugh, G., Bansal, D. and Sofat, S., Road condition detection using smartphone sensors: A survey, International Journal of Electronic and Electrical Engineering, Vol. 7, No. 6 (2014), pp. 595 - 602.

Hanatsuka, Y., Morinaga, H. and Wakao, Y., Discrimination of road-surface condition by intelligent tire - Application for winter road management -, JSSI \& JSSE Joint Conference (2010) (in Japanse).

Kamakura, T., Tanizaki, T. and Ueda, K., Development of an acoustic identification system for winter tires, IEICE Fundamentals Review, Vol. 9, No. 2 (2015), pp. 84 - 91 (in Japanese).

Kuroyama, T., Murakami, T. and Morita, E., Engine noise reduction based on linear system model for on-board measurement of tire noise, Proceedings of the Autumn Meeting of the Acoustical Society of Japan (2016a), pp. 773 -774 (in Japanese).

Kuroyama, T., Murakami, T. and Morita, E., Measurement of Tire noise considering engine noise on vehicle, Technical Report of Noise and Vibration Committee of the Acoustical Society of Japan, N-2016-53 (2016b), 4 pages (in Japanese).

Ministry of Land, Infrastructure, Transport and Tourism ed., White paper on land, infrastructure transport and tourism in Japan (2015), p. 308 (in Japanese).

Sakata, N., Murakami, T., Nakajima, H. and Nakadai, K., Wind-induced noise reduction using a small two-channel microphone array, The Jouranl of the Acoustical Society of Japan, Vol. 72, No. 12 (2016), pp. 739 -748 (in Japanese).

The Acoustical Society of Japan ed., Spectral analysis of sound and vibration(1999), Section 9.

Takahashi, Y., Tohyama, M. and Yamasaki, Y., Phase response of transfer functions and coherent field in a reverberation room, IEICE TRANSACTIONS on Fundamentals of Electronics, Communications and Computer Sciences, Vol. J89-A, No. 4 (2006), pp. 291 - 297 (in Japanese).

Ueda, K., Tanizaki, T., Nakamura, K., Onodera, H. and Kamakura,T., Road surface condition detecting method focused on tire sounds of vehicle, IEE-Japan Industry Applications Society Conference (2010), II-177 - II-182 (in Japanese).

Welch, D. P., The use of fast fourier transform for the estimation of power spectra: A method based on time averaging over short, modified periodgrams, IEEE transactions on audio and electroacoustics, Vol. AU-15, No. 2 (1967), pp. 70-73.

Yamada, M., Ueda, K., Horiba, I., Tsugawa, S. and Yamamoto, S., A study of the road surface condition detection technique based on the image information for deployment on a vehicle, IEEJ Transactions on Electronics, Information and Systems, Vol. 124, No. 3 (2004), pp. 753 - 760 (in Japanese).

Yoshida, J. and Hirano, T., Basic consideration for contribution separation of vehicle interior noise using independent component analysis (Separation of road and wind noise using only vehicle interior sounds), Transactions of the JSME (in Japanese), Vol. 80, No. 812 (2014), DOI: 10.1299/transjsme.2014trans0063. 